\title{
Contemporary urban planning: the importance and consequences of citizen participation in the processes and decisions about urban space
}

Planejamento urbano contemporâneo: importância e consequências da participação dos cidadãos nos processos e decisões sobre o espaço urbano

\section{Planification urbaine contemporaine: l'importance et les conséquences de la participation citoyenne dans les processus de décisions concernant 'T'espace urbain}

\author{
La planificación urbana contemporánea: la importancia y las consecuencias \\ de la participación ciudadana en los procesos de toma de decisiones sobre el \\ espacio urbano
}

\author{
Andréa Quadrado Mussi ${ }^{1}$ \\ Recebido em 10/01/2018; revisado e aprovado em 25/03/2018; aceito em 13/04/2018 \\ DOI: http://dx.doi.org/10.20435/inter.v19i4.1805
}

\begin{abstract}
This paper contemplates on the importance of empowering local communities to develop urban interventions. One example of such importance is observed on the revitalization of a square of Passo Fundo, RS, Brazil, conducted through a public/private partnership. A survey of user satisfaction and behavior presents the appropriation of the square. Planning, design and urban management actions performed throughout a period of eight years boosted crucial changes in the neighborhood urban dynamic.
\end{abstract}

Keywords: contemporary urban planning; empowerment of communities; urban design; urban perception; behavioral mapping.

Resumo: Este artigo reflete sobre a importância do empoderamento de comunidades locais para alavancar intervenções urbanas como a da praça de um bairro de Passo Fundo, RS, Brasil, realizada por intermédio de parceria público/privada. A pesquisa de satisfação e comportamental dos usuários mostram a apropriação da praça. As ações de planejamento, projeto e gestão urbana realizadas num período de 8 anos impulsionaram mudanças cruciais na dinâmica urbana do bairro.

Palavras-chave: planejamento urbano contemporâneo; empoderamento de comunidades; projeto urbano; percepção urbana; mapa comportamental.

Résumé: Cet article reflète l'importance de l'émancipation des communautés locales afin de faire avancer des interventions urbaines telles que celle d'une place de quartier dans la ville de Passo Fundo, RS, Brésil, réalisée par un partenariat public-privé. La recherche comportementale et de satisfaction montrent tous les deux l'appropriation de la place par les usagers. Les actions de la planification, de la conception et de la gestion urbaine menées sur une période de huit ans ont développé des changements cruciaux dans la dynamique urbaine du quartier.

Mots-clés: urbanisme contemporain; l'émancipation des communautés; design urbain; perception urbaine; cartographie comportementale.

Resumen: Este documento conduce a reflexiones sobre la importancia de empoderar a las comunidades locales para aprovechar las intervenciones urbanas, como la plaza de un barrio de Passo Fundo, RS, Brasil, realizada a través de una asociación público / privado. La encuesta de satisfacción del usuario y comportamiento presenta la apropiación del plaza. La planificación de la acción, el diseño y la gestión urbana tomado durante un período de ocho años impulsó cambios cruciales en la dinámica urbana del barrio.

Palabras clave: urbanismo contemporáneo; empoderamiento de las comunidades; diseño urbano; percepción urbana; mapa de comportamiento.

\footnotetext{
${ }^{1}$ Faculdade Meridional (IMED), Passo Fundo, Rio Grande do Sul, Brasil.
} 


\section{THE NECESSARY PERFORMANCE PERPETUATION OF SOCIAL ACTORS IN URBAN DYNAMIC QUALIFICATION}

One of the challenges of contemporary urban planning is to perpetuate the performance that social actors have been playing in the qualification and production of urban space. Especially those organized into associations that include inhabitants, companies and institutions (religious, higher education etc.) of a particular neighborhood.

The required challenges to qualify the urban spaces and energize the city are so many that isolated effort of public power is not enough. Thus, it is important to join efforts and to seek joint actions by public/private partnerships.

It also opens up opportunities for social entrepreneurs and entities to reaffirm themselves and show greater performance in the requalification of urban spaces, required to meet social demands in the city.

Social organizations and public/private partnerships own the endorsement of the Estatuto da Cidade (or City Statute, a brazilian legislation of 2001) which intensified the performance of social entities with the endorsement of this legislation. The general guideline of Estatuto da Cidade (article 2으. especially subsections I, II and III), where it deliberate about city rights, the importance of community participation in county councils and public audiences, and incentive shared management between public power, citizens and public/private partnerships, are some examples of crucial changes in the urban dynamics.

The contemplation of the importance of empowering local communities to develop urban interventions that improve the quality of life of inhabitants without exclusive dependence of public power, is presented in this paper.

At the moment, these interventions are visible and generate a multiplier effect, propitiating new actions, until they become a habit. Facts and actions integration can culminate in significant transformations in space appropriation and in urban dynamics with repercussions that go beyond the immediate surroundings, with beneficial effects for the whole city.

These contributions arise from the endeavor of Associação dos Amigos da Praça Santa Teresinha (AAPST- Association of Friends of Santa Teresinha Square, brazilian nongovernmental organization) and Higher Education Institute in the Rodrigues neighborhood in Passo Fundo, RS, Brazil. This leads one to consider that urban changes in a given locality can occur in different ways and are not the sole responsibility of the public power.

This work highlights the trajectory and repercussion of urban interventions in Capitão Jovino Square promoted by AAPST and Higher Education Institute. The actions carried out relate to the rescue of the historical and cultural memory of Capitão Jovino Square and its surroundings, through testimonies of people who lives there from 20 to 60 years, photos and old news; the collection of people's perceptions regarding intervention priorities in Capitão Jovino Square and surroundings; and post-occupancy evaluation of the post-intervention square. This evaluation was carried out after 3 and 5 years of the main requalification made in the square, by means of objective questions and semi-structured interviews to users. Also, more recently, it was made an analysis of square appropriation, by observation and registry in a behavioral mapping. The citizenship practice is inherent in contemporary thinking about the development of cities. It is possible to stimulate this practice by increasing community articulation and volunteering for the realization of urban interventions that promote the improvement of the local quality of life. 
The scope of public power is limited, considering that the main commitment of the Brazilian government is in other areas such as education, health and housing, it often leaves aside the qualification of open spaces. As a consequence, neighborhoods' urbanity has been declining in quality, making the qualification of these spaces by public/private partnerships an alternative. Making the mediation between public and private sectors, the local community is an important agent, since users with appropriate participation techniques can negotiate proposals that will have a greater power in capturing private resources and in the requalification of idle, degraded or low appropriated spaces.

The empowerment of local communities is an alternative to increase a collaborative and supportive spirit between the people, to promote welfare for all, conferring greater membership and often enabling urban requalification altogether in neighborhoods.

The term empowerment, here understood as empowering society through self-management of enterprises and production of space, arises in the 1970s, seeking to highlight community participation and organization, composing the initial works that relate power and poverty (LIMA, 2008). Other important concept that emerges in Brazil in the 1990s, with great power of social transformation and impact is social entrepreneurship, which involves many skills such as responsibility, vision, team work, in addition to inspire other people (OLIVEIRA, 2004; PINTO et al., 2016).

This networks can count on government or private entities for help, like facilitators of the process, but not as leaders. The action must take advantage of a population desire for a change. It is a bottom-up process that starts from the base: the population, to the top: the government.

Community participation that entails consequences in planning, management and in the elaboration of urban designs are based on attitudes like the bottom-up approach, thus mobilizing social actors and private resources in order to modify a decaying urban dynamic and requalify urban spaces for public use.

The multiplier effect that any local action generates in other neighborhoods makes a significant contribution to urban interventions, taking into account that the city can be understood as an open and complex system, composed of interconnected cells and with successive influence in its neighborhood. A system that is composed of several elements: people, vegetation, roads, urban furniture, buildings, among others. It is open since it is constantly changing, and complex because these elements interact in various ways, in which people, the main users of space, possess different perceptions and cognitions reflected in their life experiences, worldviews, formal and practical knowledge, convergent and/or divergent interests.

Cities reflect the values, commitment and resolution of the societies that surround them. The success of cities depends on their inhabitants, their government and the priority they both give to building a humanized urban environment. Strengthening community engagement and empowering the population is therefore essential. Park (1967, p. 34) mentions (our translation) that "[...] Through time, every sector and block of the city assumes something of the character and qualities of its inhabitants".

So the city is also a reflection of its population. Any intervention in the city must take into account, obtain, reinforce or recreate certain elements in the physical structure of the city. These values can be expressed by the properties of the city. For Garcia and Rimoch (apud GEBAUER, 1983), their combination gives the concept of quality, here understood as the presence (or absence) of certain values and properties. One of the essential characteristics of the city is 
the possibility of producing and appropriating values by its inhabitants. This characteristic is dependent on the juxtaposition of certain properties such as accessibility, autonomy, identity, security, complexity, diversity, concentration, articulation, integration, dominance, contrast, definition and hierarchy.

How to make citizens' participation in the qualification of cities consistent? How to successfully mobilize social actors- public and private- in the construction of a city that has the appropriation of its citizens? These are some of the issues that the experience developed in this paper helps to answer.

\section{METHODOLOGY OF THE PLANNING ACTIONS, DESIGN AND URBAN MANAGEMENT FOR QUALIFICATION OF THE CAPITÃO JOVINO SQUARE AND SURROUNDINGS}

The region of the neighborhood "Rodrigues Ville" as it is officially named (sector 19 of Figure 1) has 5,195 inhabitants and its first allotment was inaugurated in 1918, configuring with one of the first expansions of the urban center. The neighborhood represents $2.81 \%$ of the population of the city of Passo Fundo, RS, Brazil, with 184,826 inhabitants (IBGE, 2010). It is one of the neighborhoods, along with the Lucas Araújo neighborhood (sector 7 in Figure 1), which has the highest percentage of people living there for 60 years or more (17\%). Further on, it can be observed that by this characteristic, one can interview residents who have lived in the neighborhood for 60 years.

Figure 1 - Urban area map of Passo Fundo, RS, highlighting the neighborhood Rodrigues

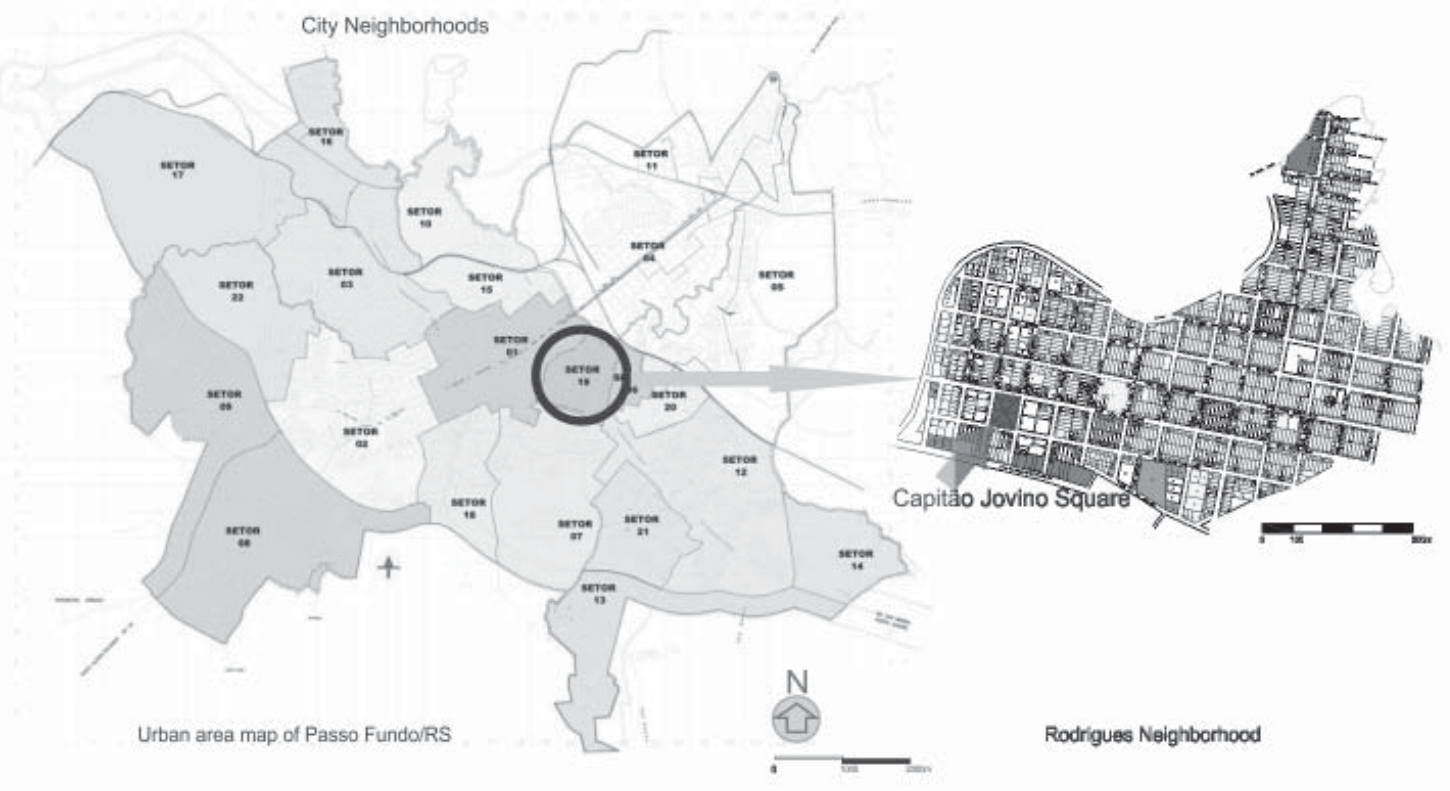

Source: Base map of Passo Fundo of the City Hall, modified by the author.

The main reference point of the neighborhood is the Capitão Jovino Square. Originally, this square was named Brazil Square and is also known as Santa Teresinha Square, due to the presence of Santa Teresinha Church, localized in front of square. This square was adopted in order to develop actions by the community. 
Actions of planning, design and urban management to the qualification of the Capitão Jovino Square and surroundings began in 2008 and continue until present days, implemented by AAPST and Higher Education Institute membership of the association. The trajectory of the main activities is described in Figure 2 and includes, with the respective year of accomplishment:

(i) 2008 - Rescue of the historical cultural memory of the Capitão Jovino Square and its surroundings, through testimonies of 14 people who live there from 20 to 60 years, old photos and news;

(ii) 2008 - Collection of people's perceptions regarding priority improvements in Capitão Jovino Square and surroundings. By means of the application of a questionnaire to 150 residents, in person and via digital questionnaire posted on a research blog;

(iii) 2009- Mobilization and creation of the AAPST;

(iv) 2010 - Elaboration of the requalification design of the square complementary to the design elaborated by the City Hall of Passo Fundo. In the complementation, it was considered electrical design, lighting, playground, outdoor gym, landscaping and multiple use building. The design was presented to the community for discussion and later to the city hall, after the adoption term was granted by the city hall to AAPST. Next, a donation campaign started to enable the project execution;

(v) 2013-2016 - Post-occupation evaluation of the post-intervention square. This study was carried out 3 years (2013) and 5 years (2015) after the year (2010) when the main requalification was performed in the square, by means of an application form with objective questions and semi-structured interview to users. More recently (2016), an analysis of the appropriation of the square was made, through the observation and registration in behavioral mappings. In this paper, the results of 2015 and 2016 studies will be presented. In 2015, 56 respondents answered the interviewer to assign one of the 5 options in a scale (great, good, regular, bad or terrible) regarding the main modifications made in the square through the execution of the design (sidewalks, outdoor gym, playground and fitness for rest and contemplation purposes); management of the maintenance and conservation of the square as a whole; as well as the quantity, conservation and maintenance, and location of urban furniture (park benches, garbage cans and bus stops in the area), and type of urban tree planting. In addition, questions about the need to install (yes or no) bathrooms, coffee bar, mini-library and internet, newsstand / magazines in or near the square itself were made. The interviewees were also asked about their neighborhood housing. 
Figure $\mathbf{2}$ - Timeline of the actions that culminated in the requalification of the Capitão Jovino Square

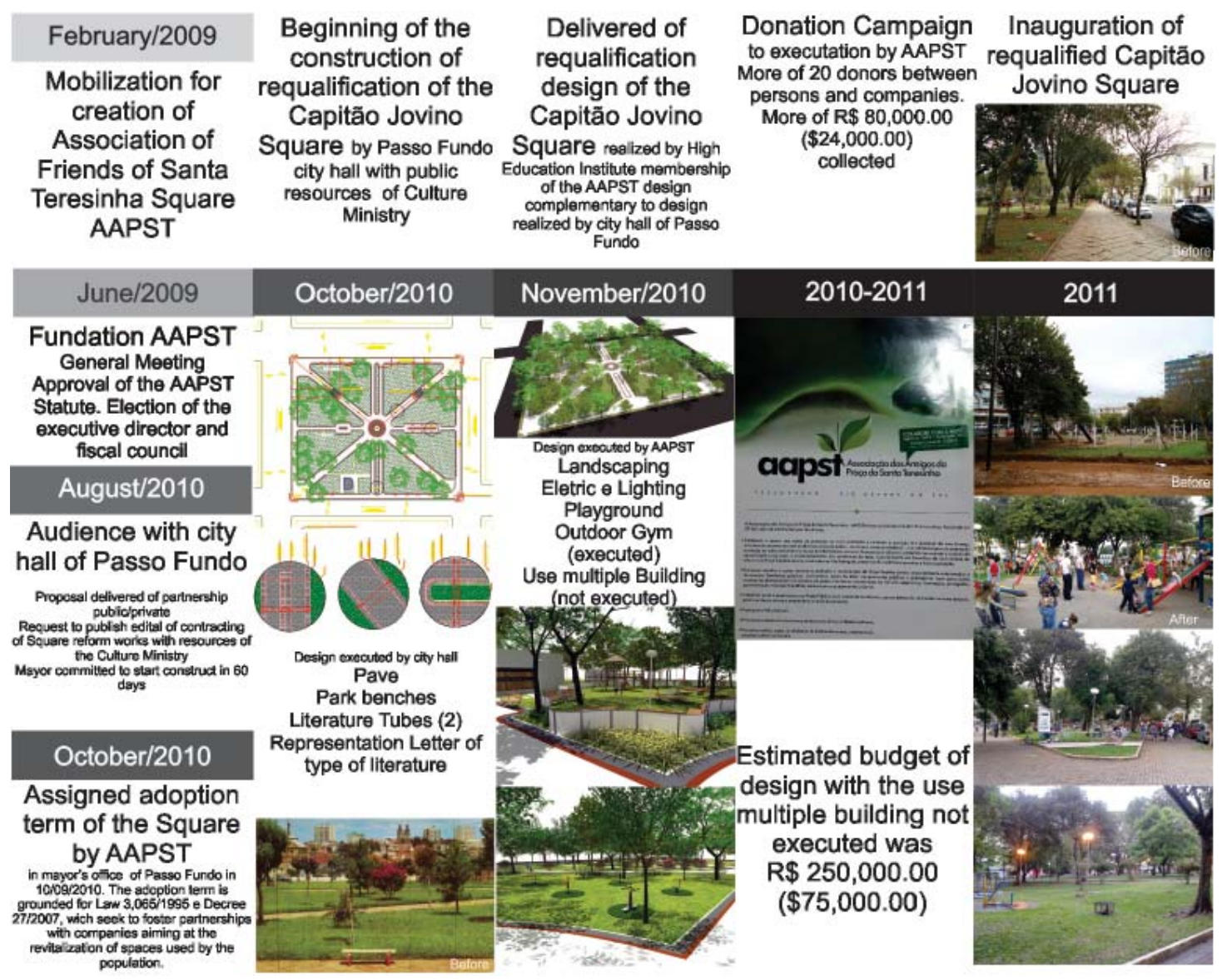

Source: Author.

\section{CAPITÃO JOVINO SQUARE AND SURROUNDINGS: CULTURAL HISTORICAL MEMORY, PRIORITY IMPROVEMENTS, URBAN QUALIFICATION AND APPROPRIATION}

For the study of cultural historical memory, all 14 interviewees mentioned that in 2008, 3 years before the interventions in the place, that the square was well located and was very important for family, children and leisure gatherings. The square is in the memory of the community, highlighted by one of the interviewees (our translation): "The history of Vila Rodrigues is in the square, when I remember the past it comes to mind from the students to the goers of the Catholic church". But the majority of respondents said the place was insecure and dangerous in 2008.

Most of the interviewees (64\%) chose to live in the Rodrigues neighborhood as a result of their parents already lived there. The other interviewees (36\%) justify the choice because they are close to their jobs and due to the facilities of the neighborhood (our translation): "because it is a healthy place, near the church and other amenities". Three of the respondents inherited the parents' businesses and said they had the opportunity to buy low priced land in the developing neighborhood.

As for the best recollections of the square and surroundings, the great majority of those interviewed remembered the festivities in the square promoted by the Santa Teresinha church, the baptisms and marriages of their children in the church, their marriages, when they took their 
children to play in the square and the sessions at the Coral cinema (it was around the square) on Sunday afternoons and after Masses.

The interviewees have lived in the Rodrigues neighborhood from 20 to 60 years, which leads the local community portrait vivid mental images of the region, and thus a greater belonging and appreciation to the neighborhood, facilitating mobilizations that lead to qualify it. One of the interviewees recalled the fund gathering for parties and fairs and the contribution to the church construction.

This feature of current resident mobilization that led to the interventions of square qualification is observed historically. Based on historical records, the local community has already mobilized efforts to promote improvements in the Capitão Jovino Square (then Brazil Square) and surroundings since 1927. This path of engagement is highlighted in Figure 3. In the community requested measures to the public power, a financial counterpart was always offered by the community to assist in improvements in the square or in the construction of the church. It is said that in 1935 the square had plenty of community resources through donations, including a project carried out by a volunteer engineer.

Figure 3 - Main facts on Rodrigues neighborhood emergence and Capitão Jovino Square, with emphasis on community engagement

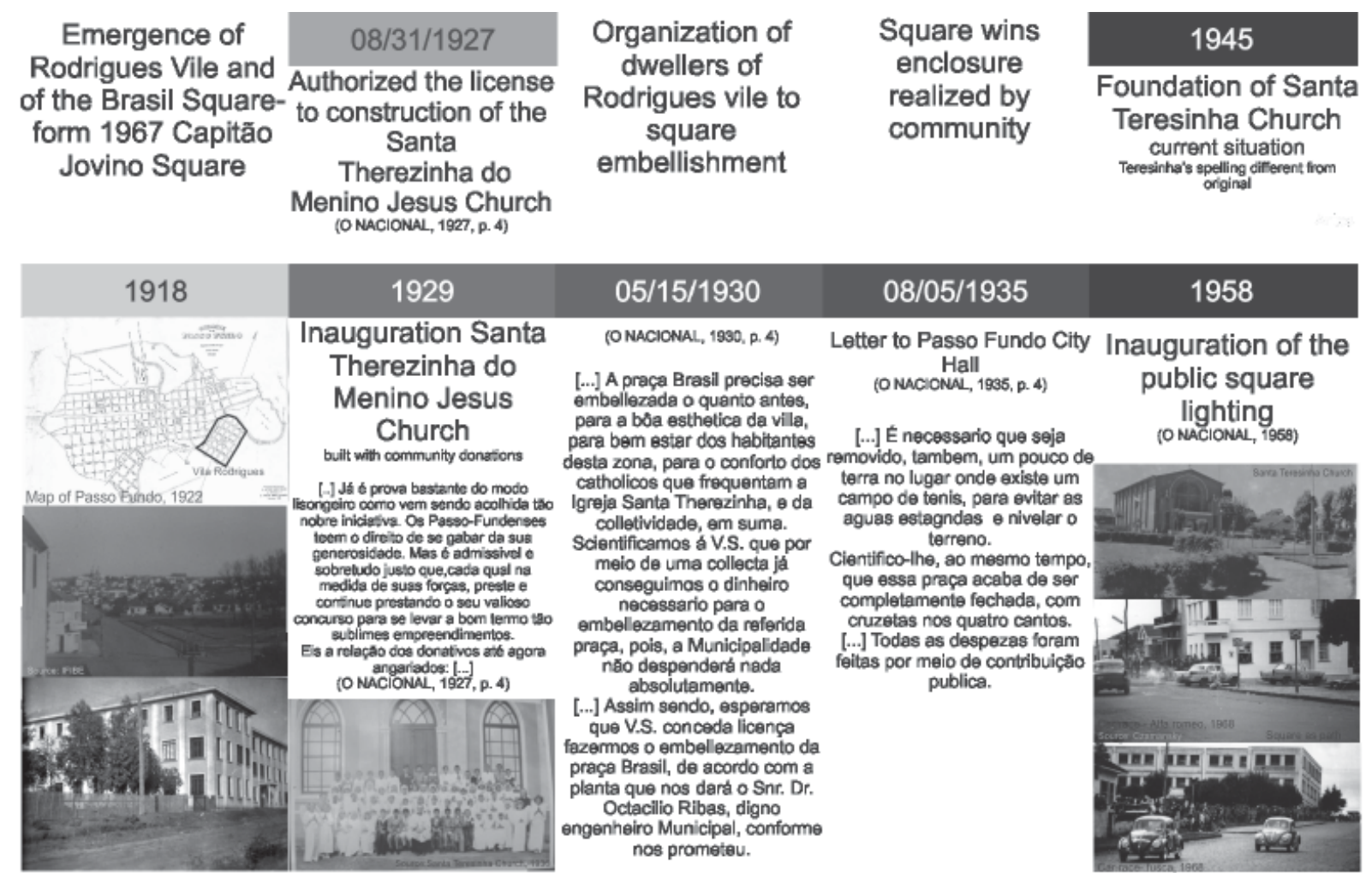

Source: Author.

In another community action, priority improvements for the square and surroundings were identified from a questionnaire applied in 2008. Priority improvements (Figure 4) identified by 150 residents were: lighting, renovation of public restrooms, garbage cans, surveillance cameras and traffic. 
Figure 4 - Priority Improvements pointed out in 2008 by the dwellers' Rodrigues neighborhood, Passo Fundo, RS

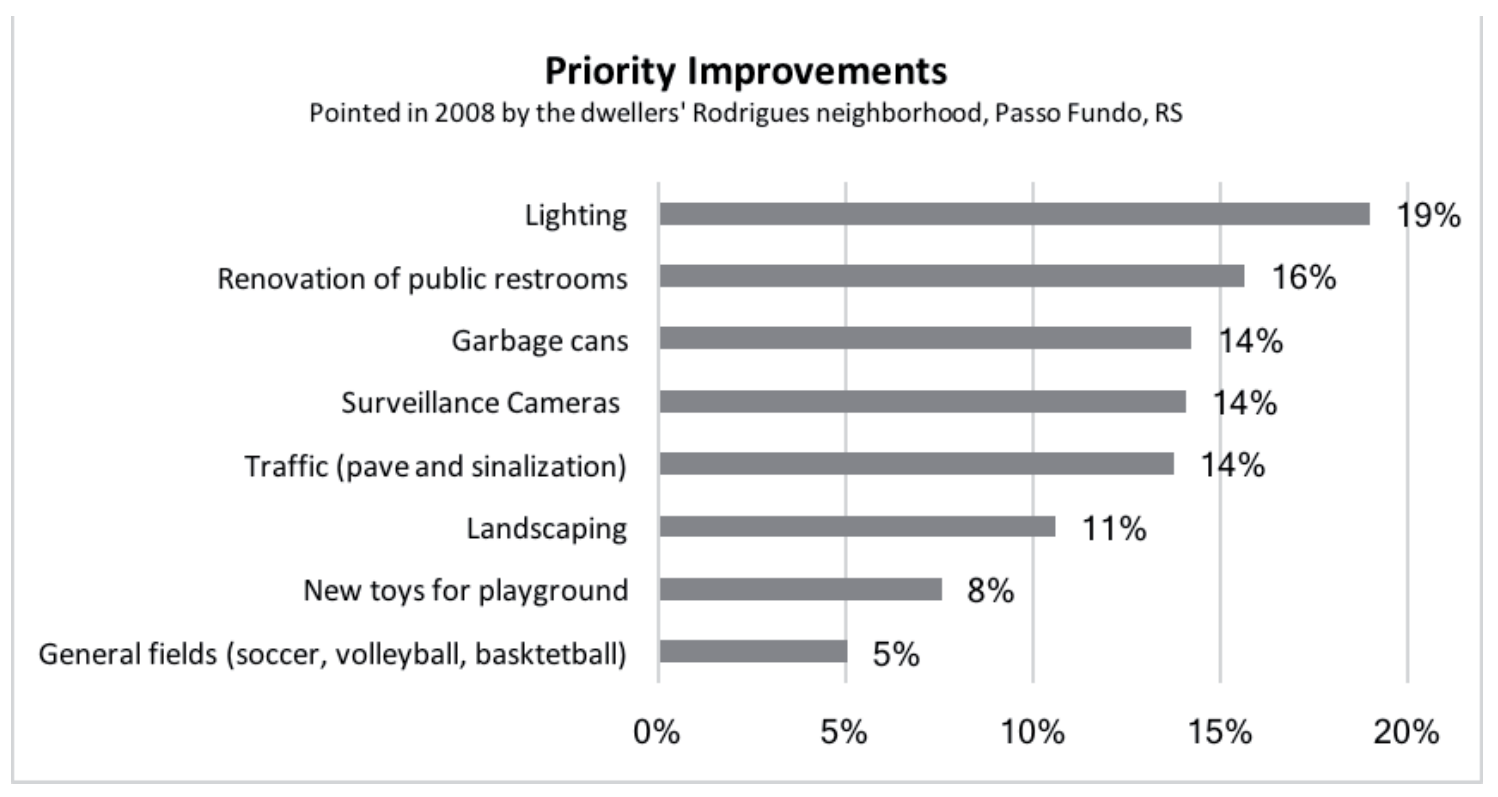

Source: Author, 2008.

These priorities were one of the benchmarks for the requalification design carried out by Higher Education Institute of AAPST, complementary to the design elaborated by the City Hall of Passo Fundo. As the donations were obtained, the rehabilitation design developed by AAPST was executed in its totality, except for the construction of the multiple use building that was not implemented.

Additionally, these priorities served as support for requesting to the city hall a change in local traffic, with proposals for modifications presented in an audience with the mayor and municipal technicians. The suggestions also involved improvement of public street lighting and pavements, and installation of surveillance cameras in the square surroundings. Therefore, in 2013 the roads around the square were paved, received high safety lanes, public street lighting received new light bulbs and surveillance cameras were installed in three corners of the neighborhood.

Something that was not contemplated so far among the priority improvements was the reform of public toilets, which are even nonexistent in the current square. This demand still persists when responses of the questionnaire applied to the users in 2015 were analyzed, when 68\% found it necessary to install public toilets in the square, while coffee bar, mini-library and internet, and newsstands / magazines are not considered necessary. This request generated a debate in the AAPST regarding the real need of public toilets inside the square, which generated the idea of incorporating this question into the post-occupation evaluation through questionnaires.

Regarding the main changes made in the square through project execution in 2010 (sidewalks, outdoor gym, playground and fitness for relaxation and contemplation purposes) and the management of maintenance and conservation of the square as a whole, the majority classified as good (Figure 5), except for the outdoor gym that needs visible repairs, highlighted in the interviewees' evaluation.

The Figures 6, 7, 8 and 9 present the results of the questionnaire regarding urban furniture and urban arboriculture. As for the quantity, conservation and maintenance, and location of the 
urban furniture benches (Figure 6) and bus stops (Figure 7) were mostly rated as good. As well as for the amount, conservation and maintenance, and type of tree planting species in the square (Figure 8). As for the quantity and location of garbage cans (Figure 9) was mostly rated as regular.

Figure 5 - Users satisfaction regarding the improvements made in the square

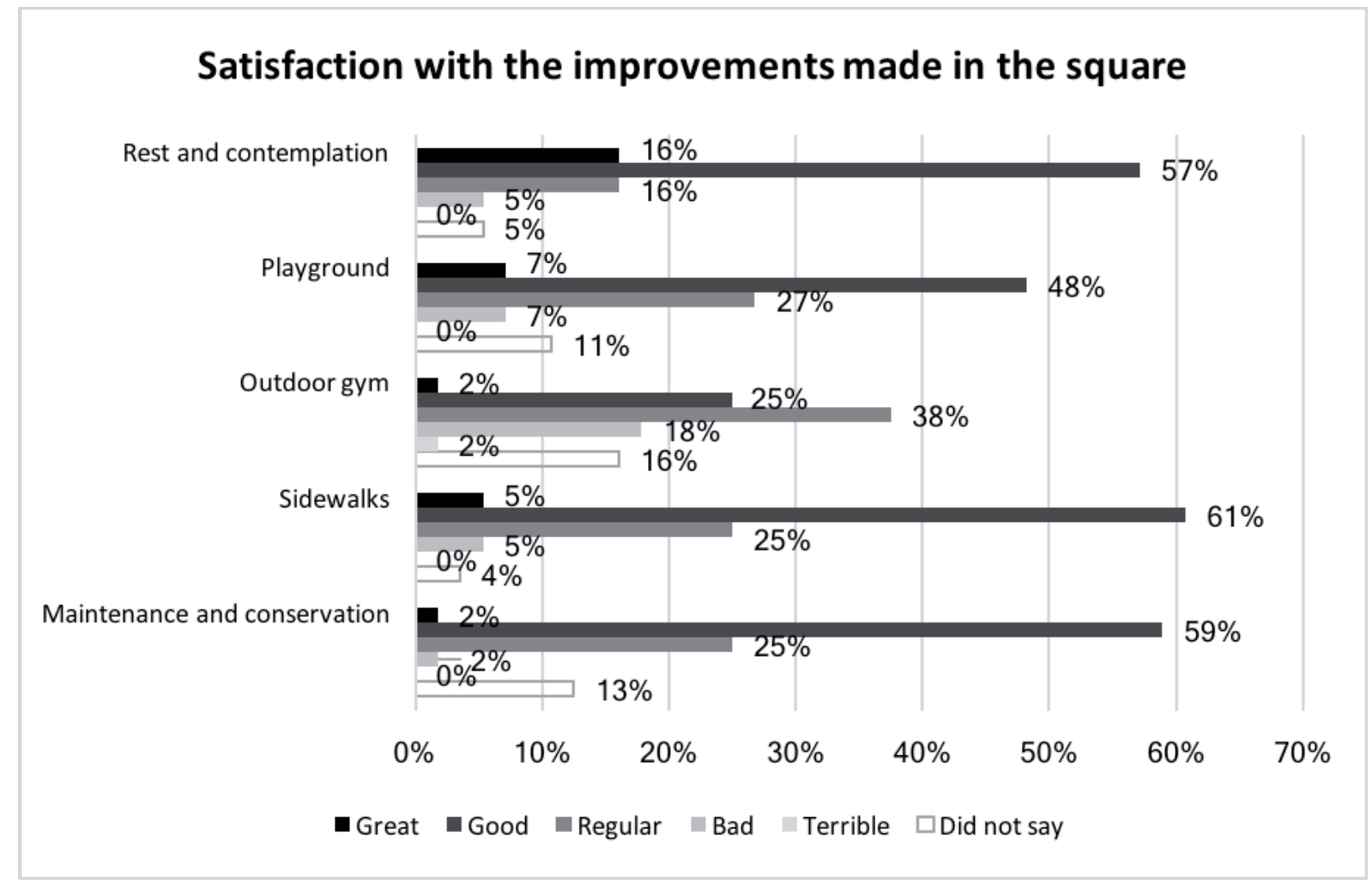

Source: Author.

Figure 6 - Users satisfaction regarding park benches

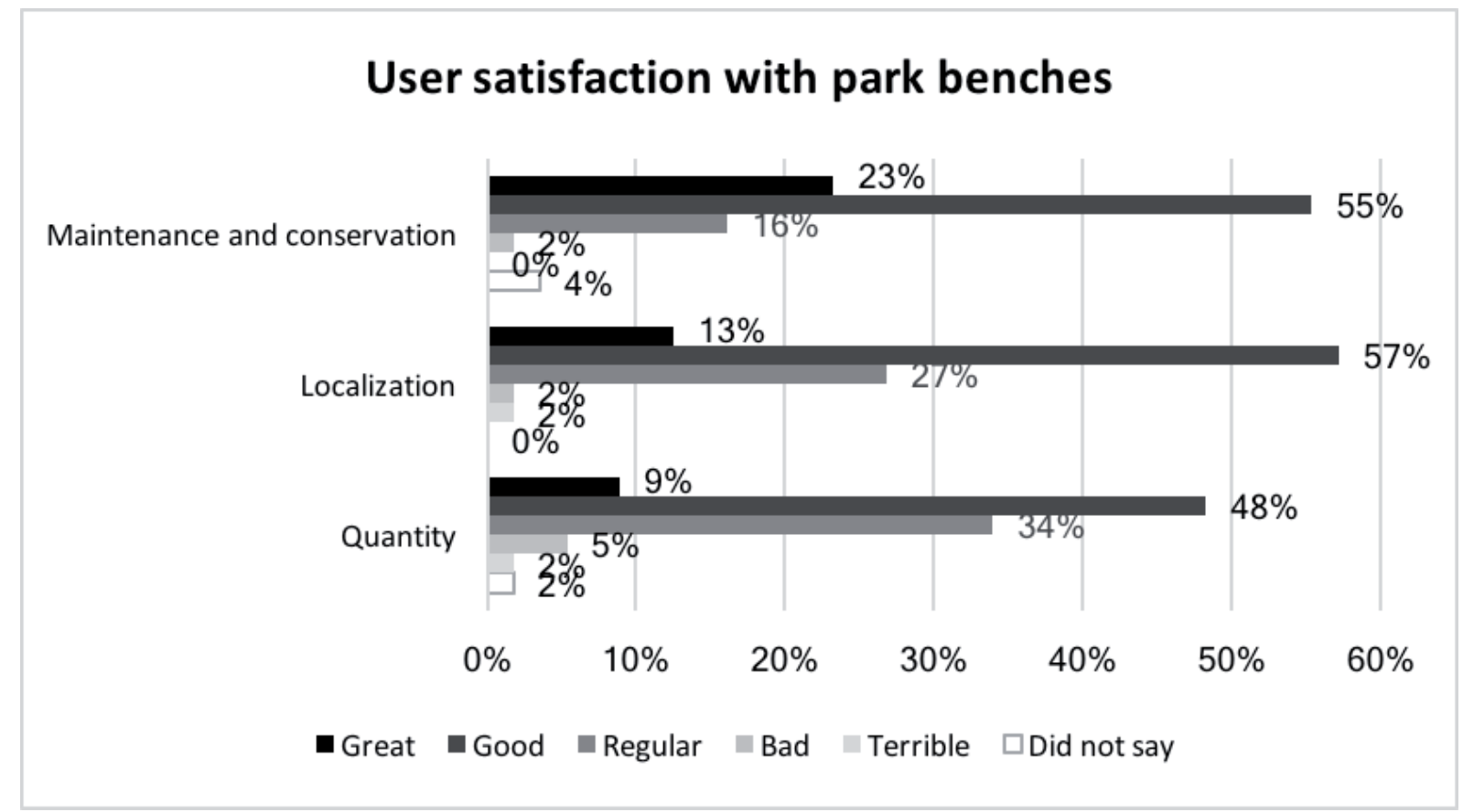

Source: Author. 
Figure 7 - Users satisfaction regarding bus stops in square surroundings

\section{Users satisfaction with bus stops}

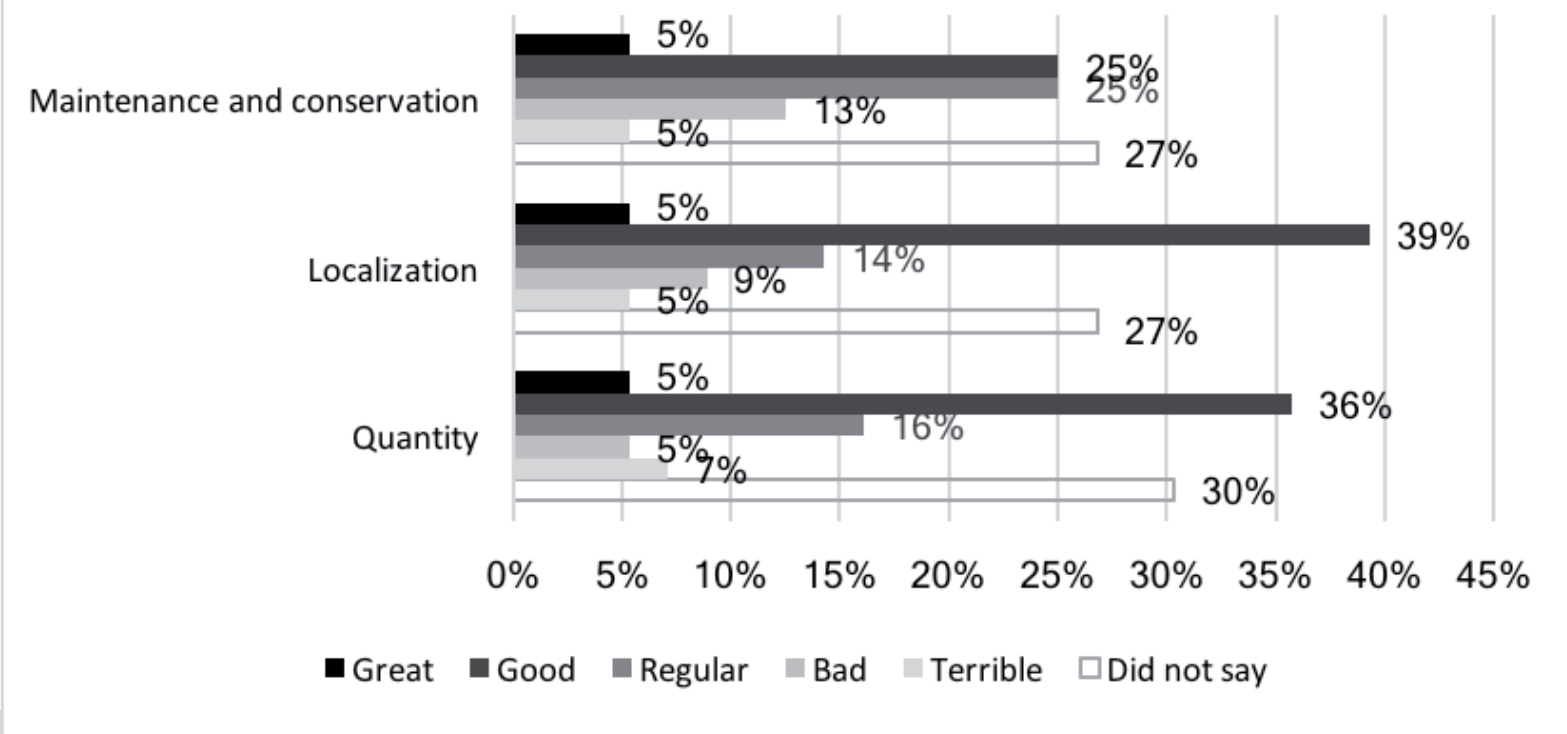

Source: Author.

Figure 8 - Users satisfaction regarding garbage cans in the square

\section{Users satisfaction with garbage cans}

Maintenance and conservation

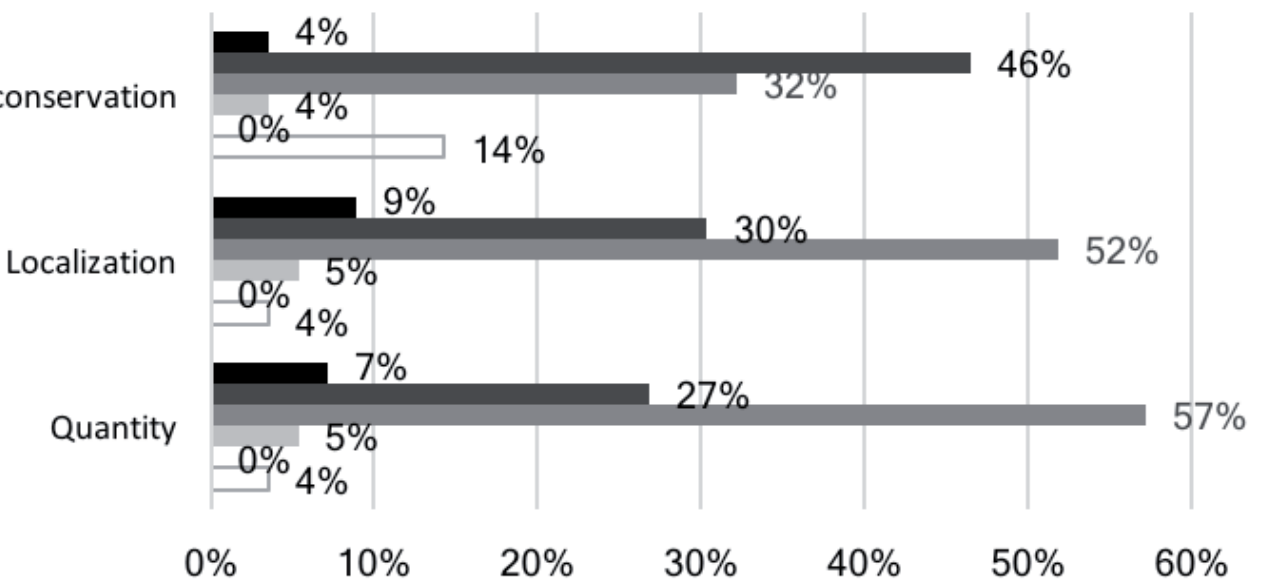

Localization

-Great $\square$ Good $\square$ Regular Bad Terrible $\square$ Did not say 
Figure 9 - Users satisfaction regarding square arboriculture

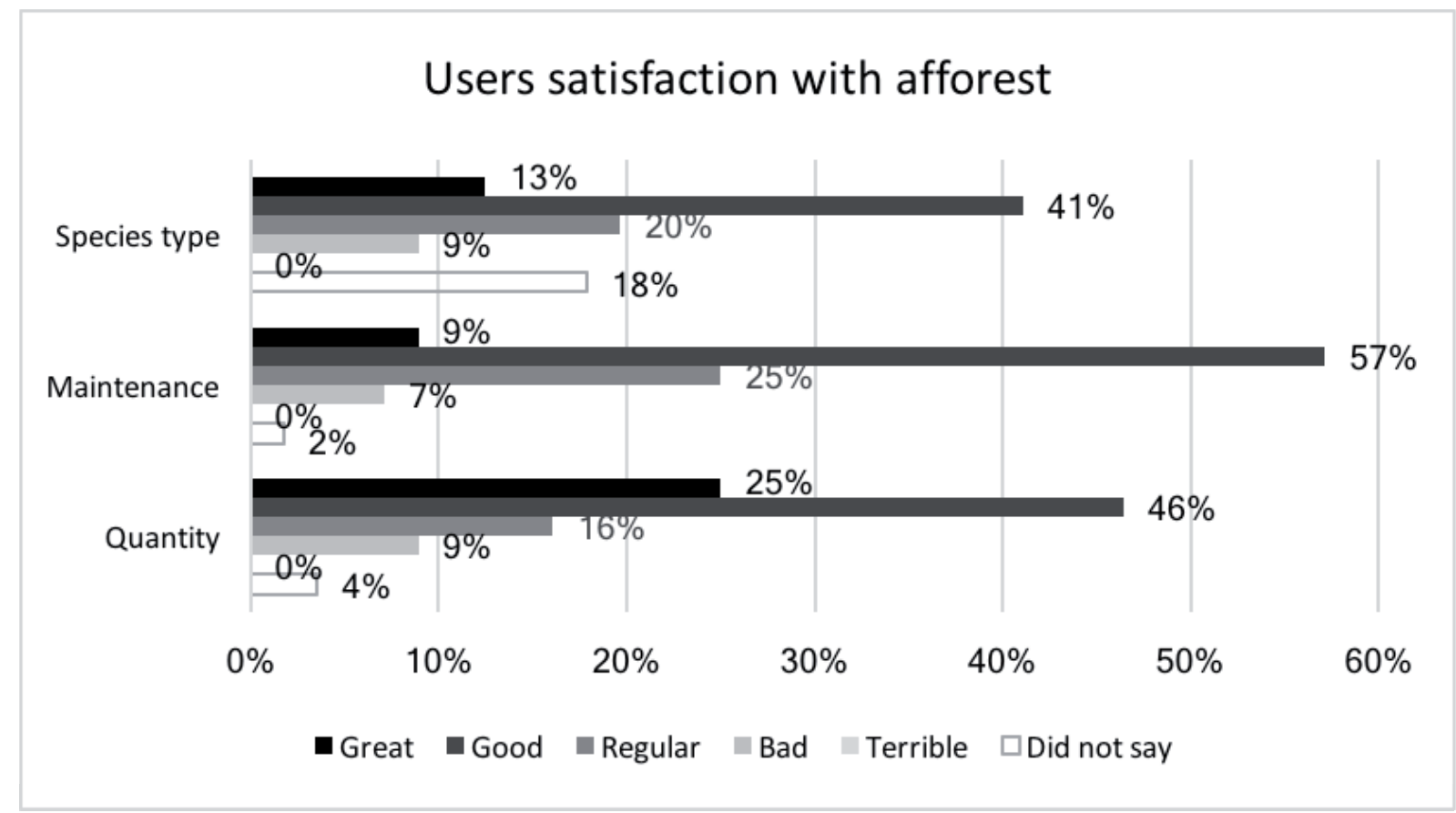

Source: Author.

As for the appropriation analysis of the square, by means of observation and registration in behavioral mapping (Figures 10 and 11), the most used place for active leisure is the playground (on the top right side in the implantation of the square). The square is most commonly used for passive leisure (rest and contemplation), with a significant increase in the number of people on weekends (Figure 11). People also circulate around the square, aiming to move from one point to another, going to nearby places of the environment (schools, commerce, restaurants and college). 
Figure 10 - Behavioral mapping observed in square from Monday to Friday in the morning and afternoon

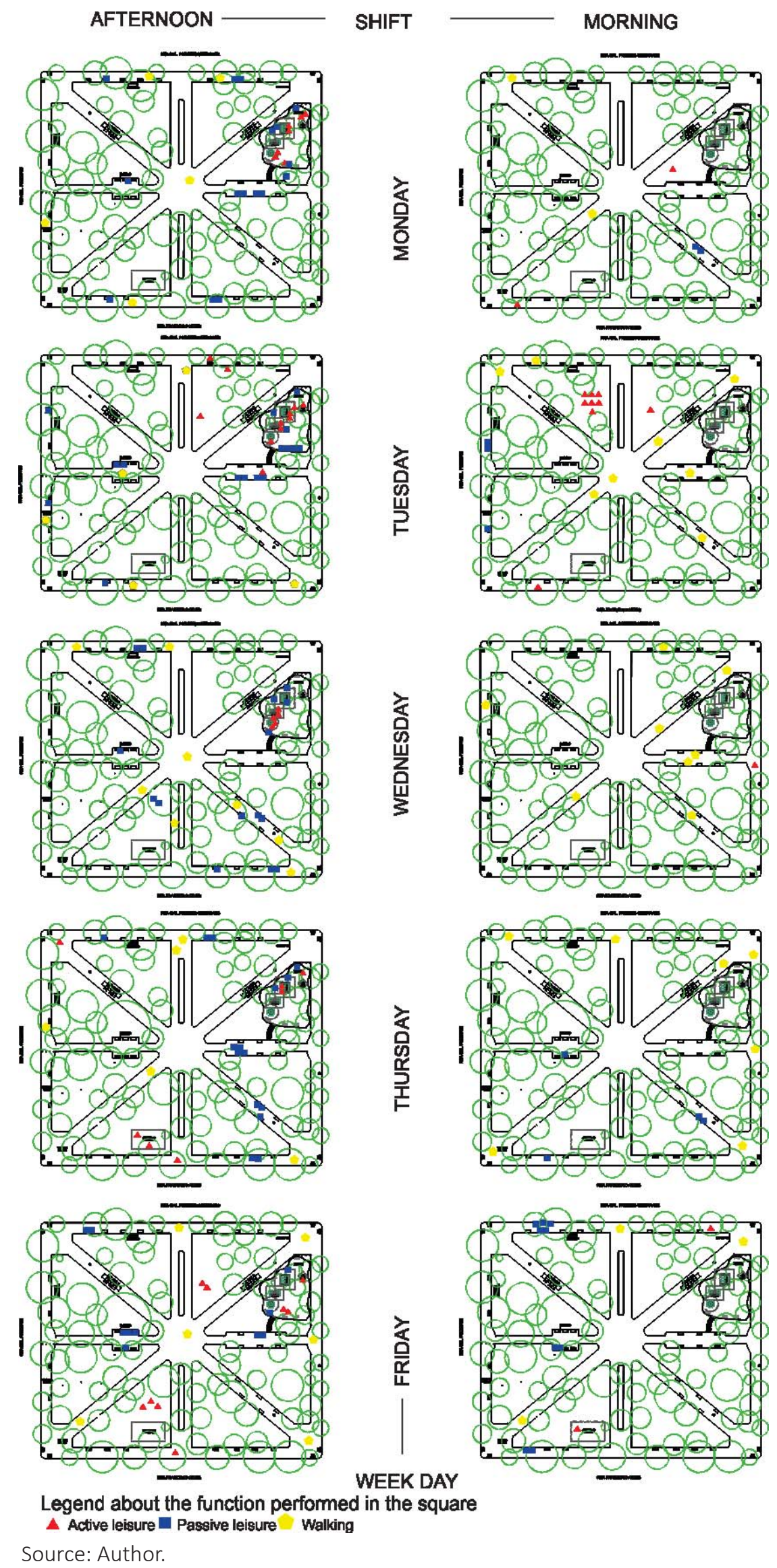


Figure $\mathbf{1 1}$ - Behavioral mapping observed in square on a weekend afternoon

SATURDAY AFTERNOON

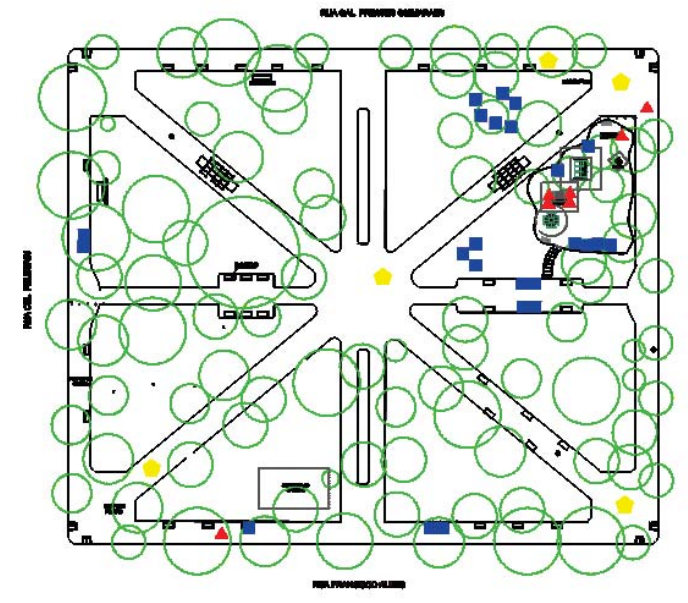

SUNDAY AFTERNOON

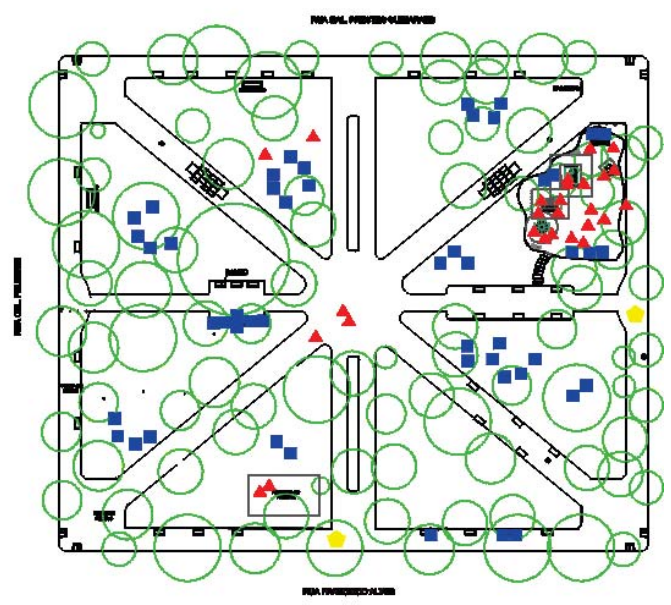

Legend about the function performed in the square

$\triangle$ Active leisure $\quad$ Passive leisure Walking

Source: Author

\section{FINAL REMARKS}

Trajectory analysis of the actions started in 2008 and extending to the present day in 2018 indicates that the mobilization of actors- public and private- had an effect on the requalification, not only of Capitão Jovino Square, but also of its surroundings, bringing benefits both to residents of the Rodrigues neighborhood, as well as all citizens of the city of Passo Fundo, RS.

The square visibility after the intervention is increasing, which can be proven by the events that have been taking place in the square since 2015, such as the Night Picnic (two editions) and Artesana Food (three editions). The advertisement of these events takes place via social media and has attracted hundreds of people from the city and region. The Artesana Food is a local gastronomy fair, which various restaurants and bars from Passo Fundo sell some of their food and beverages in the Capitão Jovino Square. At the Picnic Night, it is set up a support structure (chemical toilets) and people bring their picnic gear to enjoy with friends and family at night in the square. In addition to the implementation of new restaurants around the square (two coffee bars, two restaurants and two food trucks), indicating the commercial expansion that the region has been experiencing.

Collaborative design where the population was mobilized, and their opinion added up for an effective result, generated greater community involvement with the project and developed the sense of belonging. Thus, when the population feel that the enterprise is thought to solve their problems, the public acceptance is greater.

Collaboration networks are contemporary means of urban planning, allowing the involvement and opinion of all people who will be affected by the project. They behave in a nonlinear and nonhierarchical way and can be applied to various situations that need changes.

Most of the maintenance of Capitão Jovino Square continues to be done by AAPST (painting renovation of playground benches and toys) and there are studies of new actions, such as drawing up a master plan for the neighborhood. 


\section{Acknowledgments}

The author of this paper would like to thank the Postgraduate Program in Architecture and Urbanism (PPGARQ) of the Polytechnic School at Faculdade Meridional (IMED), Meridional Foundation (IMED), for the financial assistance through scholarships that enabled this research; Associação dos Amigos da Praça Santa Teresinha for the opportunity; Prefeitura Municipal de Passo Fundo, professors and students at IMED for the collaboration in development of the square design.

\section{REFERENCES}

GEBAUER, Maria. Urban morphology: Oxford, a place for a forum. Oxford: Oxford Polytechnic, Departments of Architecture \& Town Planning, Joint Centre for Urban Design, 1983.

LIMA, Reinaldo dos Santos. Os desafios da Responsabilidade Social Empresarial na relação com o Empowerment Comunitário: um estudo de caso da Favela do Jardim Colombo, na cidade de São Paulo. 2008. 150f. Dissertação (Mestrado em Educação) - Universidade Estadual de Campinas, Campinas, SP, 2008.

OLIVEIRA, Edson Marques. Empreendedorismo social no Brasil: atual configuração, perspectivas e desafios - notas introdutórias. Revista da FAE, Curitiba, v. 7, n. 2, p. 9-18, jul./dez. 2004.

PARK, Robert Ezra. A cidade: sugestões para a investigação do comportamento humano no meio urbano. Tradução de Sérgio Magalhães Santeiro. In: VELHO, Otávio Guilherme. O fenômeno urbano. Rio de Janeiro: Zahar, 1967.

PINTO, Ibsen Mateus Bittencourt Santana; BRUNSTEIN, Janette; MARTINS, Angelo Antônio Cavalcante; DESIDÉRIO, Paulo Henrique; SOBRINHO, Carlos Antônio Cardoso. Revisão sistemática da literatura de empreendedorismo social e desenvolvimento de competências: uma análise dos últimos 10 anos. International Journal of Innovation (IJI Journal), São Paulo, v. 4, n. 1, p. 33-45, jan./jun. 2016.

\section{Sobre a autora:}

Andréa Quadrado Mussi: PhD in Architecture. Master in Regional and Urban Planning. Professor and Researcher in the Postgraduate Program in Architecture and Urbanism of the Polytechnic School at Faculdade Meridional (PPGARQ-IMED). E-mail: andrea.mussi@imed.edu.br 